\title{
Function of Junk: Pericentromeric Satellite DNA in Chromosome Maintenance
}

\author{
MadhaV JaGANNATHAN ${ }^{1}$ AND YukiKo M. Yamashita ${ }^{1,2,3}$ \\ ${ }^{1}$ Life Sciences Institute, University of Michigan, Ann Arbor, Michigan 48109 \\ ${ }^{2}$ Department of Cell and Developmental Biology, University of Michigan, Ann Arbor, Michigan 48109 \\ ${ }^{3}$ Howard Hughes Medical Institute, University of Michigan, Ann Arbor, Michigan 48109 \\ Correspondence: yukikomy@umich.edu
}

\begin{abstract}
Satellite DNAs are simple tandem repeats that exist at centromeric and pericentromeric regions on eukaryotic chromosomes. Unlike the centromeric satellite DNA that comprises the vast majority of natural centromeres, function(s) for the much more abundant pericentromeric satellite repeats are poorly understood. In fact, the lack of coding potential allied with rapid divergence of repeat sequences across eukaryotes has led to their dismissal as "junk DNA" or "selfish parasites." Although implicated in various biological processes, a conserved function for pericentromeric satellite DNA remains unidentified. We have addressed the role of satellite DNA through studying chromocenters, a cytological aggregation of pericentromeric satellite DNA from multiple chromosomes into DNA-dense nuclear foci. We have shown that multivalent satellite DNA-binding proteins cross-link pericentromeric satellite DNA on chromosomes into chromocenters. Disruption of chromocenters results in the formation of micronuclei, which arise by budding off the nucleus during interphase. We propose a model that satellite DNAs are critical chromosome elements that are recognized by satellite DNA-binding proteins and incorporated into chromocenters. We suggest that chromocenters function to preserve the entire chromosomal complement in a single nucleus, a fundamental and unquestioned feature of eukaryotic genomes. We speculate that the rapid divergence of satellite DNA sequences between closely related species results in discordant chromocenter function and may underlie speciation and hybrid incompatibility.
\end{abstract}

\section{HISTORY OF SATELLITE DNA RESEARCH}

The term "heterochromatin" was first introduced by Emil Heitz (Heitz 1928) to describe regions of the genome that remained condensed even during interphase. A major constituent of heterochromatin is "satellite DNA," AT-rich tandem repeats, which are found in centromeric and pericentromeric regions of most of eukaryotic chromosomes. They were identified in early cesium chloride density centrifugation experiments as "satellite" bands that sedimented at different densities compared to the rest of genomic DNA because of skewed AT/GC contents (Kit 1961; Sueoka 1961; Sybalski 1968).

Despite the fact that the majority of eukaryotic centromeres are comprised of satellite DNA (Wong and Rattner 1988; Joseph et al. 1989; Willard 1990; Sun et al. 1997, 2003; Schueler et al. 2001), the lack of conservation in centromere repeat sequences, the "centromere paradox" (Henikoff et al. 2001), allied with the identification of neocentromeres lacking repeat sequences (Voullaire et al. 1993; du Sart et al. 1997; Barry et al. 1999) has led to the prevailing model that centromeres are defined in an epigenetic manner (Karpen and Allshire 1997; Allshire and Karpen 2008; Fukagawa and Earnshaw 2014). Nonetheless, satellite repeats underlying centromeres are speculated to have certain functionality to support centromeric function (Rosin and Mellone 2017).
Pericentromeric satellite DNA far surpasses centromeric satellite DNA in abundance, constituting up to $50 \%$ of genomes in certain cases (Garrido-Ramos 2017). Despite its abundance, the function of pericentromeric satellite DNA remains poorly understood. Unlike centromeric satellite DNA, whose role in chromosome segregation is indicated in kinetochore function, pericentromeric satellite DNA has been often dismissed as "junk DNA" (Ohno 1972), "selfish parasitic DNA" (Orgel and Crick 1980), or "fossils of centromeric evolution" (Malik 2009). However, many species contain substantial amounts of pericentromeric satellite DNA in their genome, whose maintenance poses a significant burden on the cell's resources. This has led researchers to speculate that pericentromeric satellite DNA may serve critical, yet unidentified roles that justify their large burden on the cell.

Cytologically, pericentromeric satellite DNA is organized into chromocenters within eukaryotic nuclei (Mayer et al. 2005). Initially, chromocenters were identified in plant cells as strongly stained foci when treated with nucleic acid dyes (Baccarini 1908). The composition of these foci remained unknown until the invention of in situ hybridization, which showed that chromocenters are dense aggregations of pericentromeric satellite DNA from multiple heterologous chromosomes (Jones 1970; Pardue and Gall 1970). Chromocenters show DNA methylation and histone methylation on H3K9/H4K20, epigenetic modifications associated with chromatin compaction and tran-

(C) 2017 Jagannathan and Yamashita. This article is distributed under the terms of the Creative Commons Attribution-NonCommercial License, which permits reuse and redistribution, except for commercial purposes, provided that the original author and source are credited. 
scriptional repression (Saksouk et al. 2015; Nishibuchi and Déjardin 2017). Much like pericentromeric satellite DNA, the role of chromocenters as a cytological structure has also remained obscure.

\section{PERICENTROMERIC HETEROCHROMATIN/ SATELLITE DNA: EXIST TO BE REPRESSED?}

Both centromeric and pericentromeric satellite DNA are heterochromatinized via similar mechanisms involving epigenetic modifications, RNAi machinery, and heterochromatin-associated proteins (Allshire and Madhani 2017; Nishibuchi and Déjardin 2017 and references therein). In brief, heterochromatin is characterized by DNA methylation and histone modifications associated with transcriptional silencing such as histone H3K9 methylation. H3K9 trimethylation, which is catalyzed by a histone methyl transferase (Su(var)3-9 in Drosophila, Suv39 and SETDB1 in mammals), is recognized by heterochromatin protein 1 (HP1), a hallmark of constitutive heterochromatin. Recruitment of heterochromatin proteins to the underlying satellite DNA requires transcription via a few mechanisms (Hall et al. 2012; Biscotti et al. 2015; Saksouk et al. 2015). First, transcription of satellite DNA leads to Dicer-dependent siRNA production, which is required for the establishment and maintenance of heterochromatin state (Bühler and Moazed 2007; Moazed 2011). Second, recent studies showed that noncoding satellite DNA transcripts recruit Suv39 enzymes to centromeric and pericentromeric sequences, leading to heterochromatinization (Johnson et al. 2017; Shirai et al. 2017; Velazquez Camacho et al. 2017). Interestingly, satellite DNA transcription has also been implicated in the formation of chromocenters in early mouse embryos (Probst et al. 2010).

Whereas heterochromatinization of centromeres has clear functional implications in chromosome segregation (Allshire and Karpen 2008; Fukagawa and Earnshaw 2014), it remains unclear why pericentromeric satellite DNA must be silenced. Its derepression has been shown to cause a plethora of problems, such as DNA damage through the accumulation of RNA:DNA hybrids (Zeller et al. 2016), chromosome missegregation, and meiotic hyper recombination (Peters et al. 2001; Bouzinba-Segard et al. 2006; Hahn et al. 2013; Tasselli et al. 2016), although it is often unclear whether these defects are caused by perturbation of centromeric or pericentromeric heterochromatin. Transcriptional derepression of satellite DNA is also associated with human pathologies such as cancer (Eymery et al. 2009; Ting et al. 2011; Zhu et al. 2011; Bersani et al. 2015), aging (Shumaker et al. 2006; De Cecco et al. 2013a, 2013b), senescence (Enukashvily et al. 2007), and cardiomyopathy (Gaubatz and Cutler 1990; Haider et al. 2012). Accordingly, most studies thus far have investigated the mechanisms of heterochromatin transcriptional silencing, based on the reasoning that its derepression is problematic. However, if pericentromeric heterochromatin serves no function, the easiest solution would be the removal of these sequences, rather than silencing through heterochromatinization. Thus, why satel- lite DNA/constitutive heterochromatin exists in the first place, and whether pericentromeric satellite DNA serves any fundamental function, is poorly understood.

\section{PROPOSED ROLES OF PERICENTROMERIC SATELLITE DNA}

Based on the reasoning that such a large component of the genome cannot be nonfunctional, many researchers have speculated roles of satellite DNAs - for example, playing structural roles or mediating meiotic homologous pairing (Yunis and Yasmineh 1971; Walker 1971; John and Miklos 1979; Kuhn et al. 2011).

One prevailing model of satellite DNA function is their involvement in meiotic homologous chromosome pairing. Cytologically, satellite DNA show strong pairing in meiotic prophase in a broad range of species (Yunis and Yasmineh 1971; Hawley et al. 1992; Dernburg et al. 1996), leading to a popular idea that satellite DNA may regulate meiotic chromosome pairing. However, earlier studies using various chromosomal deficiencies that delete most of satellite DNA (for review, see John and Miklos 1979; Miklos and John 1979) concluded that satellite DNA/heterochromatin is not required for chromosome pairing. It is possible that satellite DNA-mediated pairing may function redundantly in parallel with other mechanisms that facilitate chromosomal pairing.

Another example of putative satellite DNA function is found in the Drosophila Y chromosome. Although Drosophila Y chromosomes are highly heterochromatic, they contain several embedded genes that are required for male fertility. These genes contain megabase-sized introns consisting of satellite DNA that are transcribed in spermatocytes, forming a lamp brush-like structure termed Yloops (John and Miklos 1979; Bonaccorsi et al. 1988, 1990; Pisano et al. 1993). It has been proposed that these large intronic transcripts may fulfill a protein-binding function and sequester proteins required for later meiotic stages (Bonaccorsi et al. 1988, 1990; Pisano et al. 1993). Alternatively, intronic heterochromatin may serve to repress expression of these fertility factors in nonspermatocyte cells. However, it should be noted that it has not been possible to delete intronic satellite DNA to determine effects on the expression of fertility genes. Interestingly, a recent study suggested that intronic satellite DNA is a phenomenon specific to genes on the $\mathrm{Y}$ chromosome. By comparing the Y chromosomes of Drosophila melanogaster and Drosophila pseudoobscura, it was found that orthologous genes translocated from the D. melanogaster $\mathrm{Y}$ to a D. pseudoobscura autosome have reduced intron sizes (Chang and Larracuente 2017). Yet D. pseudoobscura spermatocytes show cytologically recognizable Y-loops, indicating that a distinct set of genes on the D. pseudoobscura $\mathrm{Y}$ chromosome have acquired mega intron(s). This implies that satellite DNA may play a role in gene expression specifically for $\mathrm{Y}$ chromosome genes, which are always maintained in a heterochromatic environment, except for once in their lifetime during spermatocyte development. 
Additional studies have indicated a role for satellite DNA transcription in response to cellular stress, most prominently during the heat shock response (Jolly et al. 2004; Rizzi et al. 2004; Valgardsdottir et al. 2008; Pezer and Ugarkovic 2012). In human cells, heat shock induces the expression of the HSF1 protein, which accumulates on nuclear stress bodies and up-regulates the transcription of the pericentromeric SatIII satellite DNA (Jolly et al. 2004; Rizzi et al. 2004). It has been proposed that the massive activation of SatIII transcription might sequester many factors required for global transcription and splicing, thus leading to downregulation of transcription under stress (Biamonti and Vourc'h 2010). Likewise, human SatII, whose transcription is up-regulated in cancer cells, has been shown to sequester the MeCP2 (methyl CpG binding) protein, demonstrating the ability of satellite DNA transcripts to regulate the epigenetic state (Hall et al. 2017). In yet another example, satellite DNA transcripts from the Drosophila X chromosome are processed into small RNAs, promoting X chromosome recognition for dosage compensation in somatic cells (Menon et al. 2014; Joshi and Meller 2017).

These studies have highlighted the importance of satellite DNA in various biological processes. However, most of these examples of satellite DNA function pertain to species-specific phenomenon, and a unifying theme underlying satellite DNA function across eukaryotes is still lacking.

\section{CHROMOCENTER BUNDLING PROTEINS}

Studying the function of satellite DNA is challenging for obvious reasons. Foremost is the inability to remove these repetitive sequences, which can span megabases on chromosomes. Therefore, we initiated our study on the function of satellite DNA by focusing on satellite DNAbinding proteins, specifically, D1 in Drosophila and HMGA1 in mouse. Both proteins contain multiple AThook motifs, which bind the minor groove of AT-rich DNA (Reeves and Nissen 1990; Huth et al. 1997). D1 was identified as a nonhistone chromosomal protein (Rodriguez Alfageme et al. 1980), which was subsequently shown to have affinity for the $1.672 \mathrm{~g} / \mathrm{cm}^{3}$ satellite DNA $\left(\{\mathrm{AATAT}\}_{n}\right.$ ) from Drosophila (Rodriguez Alfageme et al. 1980; Levinger and Varshavsky 1982a, 1982b). The $\{\text { AATAT }\}_{n}$ satellite comprises a substantial fraction of Drosophila genome at nearly $\sim 8 \%$ of the genome (Lohe et al. 1993). A role for D1 in constitutive heterochromatin has been suggested based on its effects on position effect variegation (Aulner et al. 2002).

HMGA1 (HMG-1/Y) was also identified as a mammalian nonhistone chromosomal protein (Goodwin et al. 1973; Lund et al. 1983). Further studies revealed its ability to bind satellite DNAs (Strauss and Varshavsky 1984), primarily the abundant pericentromeric satellite DNA called "major satellite" in mouse (Vissel and Choo 1989; Radic et al. 1992), which comprises nearly $6 \%$ of the genome (Lyon and Searle 1989). Consistent with the notion of pericentromeric heterochromatin forming chromocenter (Jones 1970; Pardue and Gall 1970; Guenatri et al. 2004), HMGA1 localizes to mouse chromocenters (Brocher et al. 2010).

We have found that both D1 and HMGA1 are required for clustering of chromocenter, suggesting a role of these satellite DNA-binding proteins in chromocenter formation (Fig. 1). In vitro experiments showed that HMGA1 could cross-link DNA molecules through its multiple AT-hooks (Vogel et al. 2011), suggesting HMGA1's biochemical capacity to cross-link multiple DNA strands. In an in vivo experiment, it was shown that exogenous expression of D1 in Drosophila salivary glands resulted in the ectopic fusion of heterologous chromosomes, likely at sites of intercalary heterochromatin (Smith and Weiler 2010). These published results and the fact that D1/HMGA1 are required for chromocenter formation led us to propose a model that D1 and HMGA1 are multivalent DNA-binding proteins capable of bundling multiple DNA strands, allowing clustering of pericentromeric satellite DNA from multiple chromosomes into chromocenters (Fig. 1). We found that exogenous expression of D1 protein, which can bind to mouse major satellite DNA, was sufficient to enhance the clustering of chromocenter in mouse cells, demonstrating the ability of D1 to facilitate the association/cross-linking of satellite DNA.

More direct evidence for D1 cross-linking its target DNA came from a protein fusion of D1 and LacI, which was sufficient to recruit euchromatic LacO repeat sequences into chromocenters. Finally, we observed chromatin threads, which are positive for D1/HMGA1 proteins, as well as their target satellite DNA sequences, connecting multiple chromosomes in early prophase cells, when individual chromosomes start condensing in preparation for mitosis. We speculate that these threads connecting prophase chromosomes are remnants of interchromosomal connections during interphase, which bundles chromosomes together into chromocenters. These threads are reminiscent of earlier observations of threads connecting mitotic chromosomes (Takayama 1975; Burdick 1976) that have later been shown to contain satellite DNA (Kuznetsova 2007).

Taken together, we propose that these satellite DNAbinding proteins (and perhaps other uncharacterized proteins that are known to bind to satellite DNA) participate in chromocenter formation by cross-linking their target DNA on multiple chromosomes.

\section{FUNCTION OF CHROMOCENTER IN ENCAPSULATING THE FULL COMPLEMENT OF GENOME INTO A SINGLE NUCLEUS}

The disruption of chromocenter formation in D1 mutant flies and HMGA1 knockdown cells provided a unique opportunity to interrogate the function of chromocenter/ satellite DNA. We found that disruption of chromocenter upon D1/HMGA1 depletion resulted in a dramatic increase in micronuclei formation. Time-lapse live imaging revealed that the micronuclei formed during interphase, where micronuclei bud off from the rest of the nucleus. These results indicate that cross-linking of pericentro- 


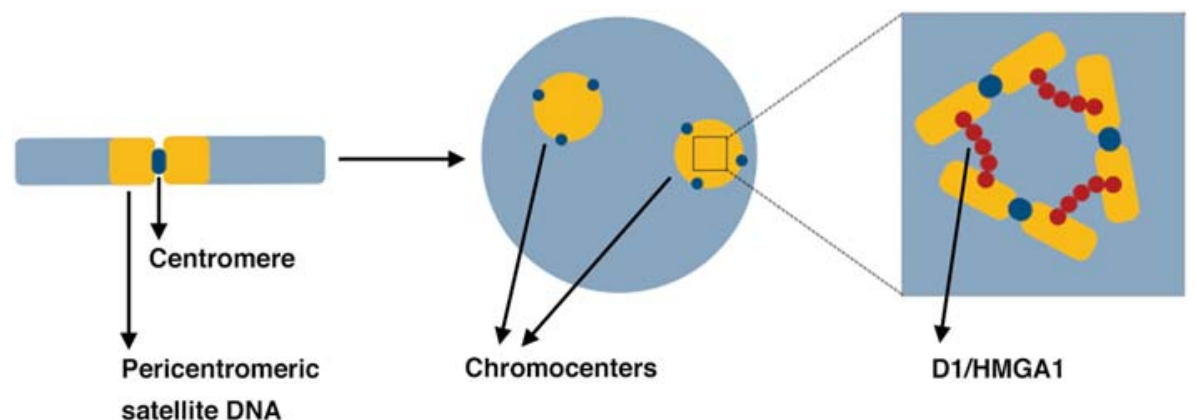

Figure 1. Model of chromocenter formation. Pericentromeric satellite DNA (yellow) is bound by satellite DNA-binding proteins (D1/ HMGA1), which cross-link satellite DNA from multiple chromosomes, leading to chromocenter formation.

meric heterochromatin is important to form a physical network of chromosomes such that individual chromosomes do not float away from each other, leading to micronuclei formation (Fig. 2).

Packaging of the full complement of the genome into a single nucleus is a fundamental requirement for eukaryotic cells, whose genetic material is split into multiple chromosomes. Packaging of the genome in a single compartment must be a prerequisite for concerted gene function, for example, to allow a transcription factor to find its target genes. The importance of maintaining a single nucleus (i.e., prevention of micronuclei formation) has been shown by series of studies that demonstrated that (1) micronuclei exhibit defective DNA replication/DNA repair and increased DNA damage (Crasta et al. 2012), (2) micronuclei exhibit defective nuclear envelope integrity (Hatch et al. 2013), and (3) chromosomes within micronuclei are susceptible to chromosome shattering and rearrangements, termed chromothripsis (Hatch and Hetzer 2015; Zhang et al. 2015), which has been suggested to be a driver of oncogenesis. Similar to these micronucleiassociated defects, D1 mutation/HMGA1 knockdown resulted in accumulation of DNA damage and chromosomal breaks, leading to cell death. These results indicate that chromocenter formation, mediated by D1 and HMGA1, plays a critical role in encapsulating the full genome into a single nucleus, a failure of which leads to micronuclei formation and the resulting cellular defects.

Interestingly, even major nuclei showed defective integrity of the nuclear envelope in D1 mutant/HMGA1 knockdown cells. This suggested that chromocenter formation might be required not only for encapsulating all chromosomes into single nucleus, but also for maintaining nucle- ar envelope integrity. Early cytological studies showed that constitutive heterochromatin was juxtaposed to the nuclear envelope and around nucleoli (Rae and Franke 1972). Because of the enrichment of heterochromatin at the nuclear envelope, it is thought to function as a gene repressive compartment. Global analysis of gene expression at the nuclear envelope has shown that genes within lamin-associated domains (LADs) generally show decreased expression compared to genes outside of laminassociated domains (Guelen et al. 2008). How do changes in constitutive heterochromatin clustering affect the integrity of the nuclear envelope? Interestingly, constitutively localized LADs are enriched for H3K9 methylation, are AT-rich and have been suggested to function as a structural backbone for the organization of interphase chromosomes (Meuleman et al. 2013). In addition, recent studies have shown that impairing heterochromatin using either RNAi of Prdm3/16 (Pinheiro et al. 2012) or chemical inhibitors of histone methyltransferases (Stephens et al. 2018) results in defects of the nuclear envelope. Because the majority of chromocenters are localized to the nuclear periphery (Mayer et al. 2005), chromocenter-forming proteins such as D1/HMGA1 may perhaps function by linking constitutive heterochromatin to nuclear envelope, or by facilitating nuclear envelope formation around the constitutive heterochromatin.

\section{IS CHROMOCENTER FUNCTION UNIVERSAL?}

We have presented the hypothesis that pericentromeric satellite DNA mediates chromocenter formation, which

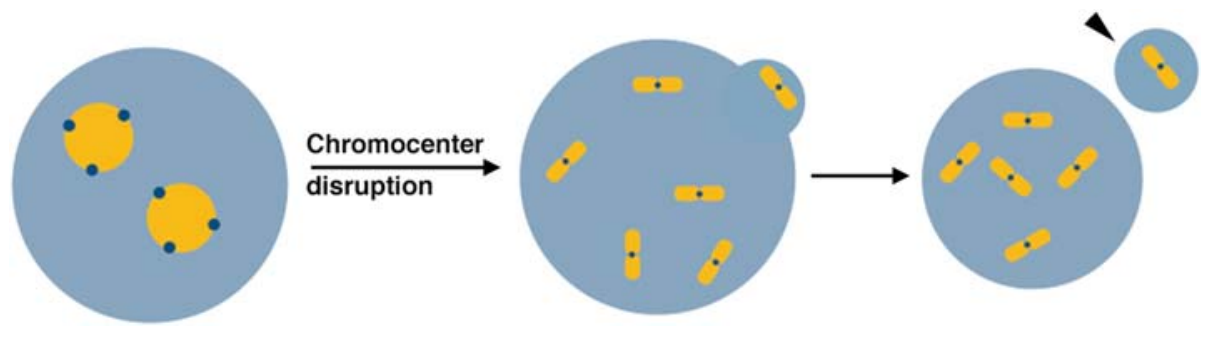

Figure 2. Chromocenter disruption leads to micronuclei formation. Loss of satellite DNA-binding proteins, D1/HMGA1, leads to micronuclei formation. Based on this result, we propose that bundling of multiple chromosomes via formation of chromocenter is critical to maintain the full complement of the genome into a single nucleus. 
functions to encapsulate the full set of chromosomes into a single nucleus. Given the ubiquity of satellite DNA, we postulate that chromocenter formation and function may be a universal mechanism conserved across many species.

This hypothesis leads to a few speculations that may provide further insights into the biology of chromocenter. First, in certain cases, eukaryotic chromosomes appear to be completely lacking satellite DNA (e.g., horse chromosome 11, orangutan chromosome 12) (Wade et al. 2009; Piras et al. 2010; Locke et al. 2011) raising the question of if/how these chromosomes may be incorporated into chromocenters. Interestingly, a recent report has shown that transposable element (TE)-derived tandem repeats are a component of mouse chromocenters (Kuznetsova et al. 2016). TE-derived sequences are abundant, heterochromatinized and typically interspersed throughout eukaryotic chromosomes (Saksouk et al. 2015; Nishibuchi and Déjardin 2017), including pericentromeric heterochromatin, where they are present in complex islands within large satellite DNA tracts (Sun et al. 1997, 2003). In addition, satellite DNA is derived from transposable elements in certain cases (Heikkinen et al. 1995; Kapitonov et al. 1998; Kidwell 2002). Recognition of TE-derived repeats or their heterochromatic nature may help chromocenter formation, possibly mediating incorporation of satellite DNA-free chromosomes into chromocenters. Thus, chromosomes lacking typical satellite DNA might still participate in chromocenter formation via their resident TEs. Also, if TE-derived sequences indeed function to mediate chromocenter formation, it may force us to reconsider the biological status of TEs: instead of pure parasites, they may be symbionts of eukaryotic genomes.

The hypothesis that pericentromeric satellite DNA may be a critical component of chromosomes to ensure its maintenance leads to another interesting consideration. Generally, repetitive sequences are thought to be inherently unstable because of sporadic loss of copy number caused by intrachromatid recombination (Charlesworth et al. 1994; Stephan and Cho 1994). If satellite DNA were a critical structural component of the chromosome, it would have to be actively maintained. This is consistent with the fact that satellite DNA shows little within-species variation in the genomes of Drosophila species despite its potential instability (Bosco et al. 2007). Strikingly, it has been shown that satellite DNA can expand in cancer cells (Bersani et al. 2015). Although it was regarded as an "abnormality" of cancer cells, it might reflect the acquired immortality of cancer cells. Similar to the telomere maintenance mechanism, which is confined to immortal cells (germ cells, some somatic stem cells, and cancer cells), maintenance (expansion) of satellite DNA may be a privileged process that can only occur in immortal cells.

\section{SPECULATION: SATELLITE DNA AND SPECIATION}

It is widely appreciated that satellite DNA sequences are highly divergent even among closely related species (Ugarković and Plohl 2002). Rapid changes in the spec- trum of satellite DNAs (dramatic expansion and shrinkage of a particular repeat sequence, leading to a vastly distinct landscape of satellite DNA composition in closely related species) has been attributed to processes such as intrachromatid recombination, unequal sister chromatid exchange, replication slippage, rolling circle amplification and reinsertion, and gene conversion (Charlesworth et al. 1994). The "library" hypothesis complements this idea, by postulating that each species does not entirely lose or acquire certain satellite repeat sequences but instead the related species share a common library of satellite sequences that merely fluctuate in copy number (Salser et al. 1976; Fry and Salser 1977).

Irrespective of the mechanisms that explain birth and death of satellite DNA repeat sequences, the highly divergent sequences of satellite DNA reinforced the idea that they are junk (Ohno 1972; Orgel and Crick 1980). On the other hand, the very same fact led to a speculation that rapid changes in satellite DNA sequences may underlie speciation, making two species incompatible with each other (Walker 1971; Yunis and Yasmineh 1971; John and Miklos 1979). Our hypothesis that satellite DNA is required for chromocenter formation can potentially offer an answer to this paradox. If satellite DNA functions as a platform for proteins that have the capacity to cross-link multiple DNA strands, the repeat sequence per se might not matter as much as its ability to be bound by crosslinking proteins (i.e., chromocenter proteins). If this is the case, evolutionary pressure will select for recognition of satellite DNA by binding proteins with less stringency for the exact sequence, which may rapidly change because of the inherent instability of repetitive DNA.

Now we are presented with a striking possibility: The rapid change in satellite DNA sequences over the course of evolution might quickly separate two populations within a species, because rapid changes in satellite DNA sequences must be matched by rapid changes in satellite DNA-binding proteins. Two populations may therefore be reproductively isolated because their satellite DNA and chromocenter-forming proteins become incompatible. If this is the case, hybrid incompatibility may arise from the incompatibility of chromocenter-forming factors (satellite DNA-binding proteins and their cognate repeat sequences) (Fig. 3). This is certainly a testable prediction, and encouragingly, the majority of speciation genes identified thus far bind constitutive heterochromatin (Sawamura 2012). For example, two hybrid incompatibility genes in Drosophila, Hmr and Lhr (Watanabe 1979; Hutter and Ashburner 1987; Barbash et al. 2003; Brideau et al. 2006), are known to localize to the chromocenters of polytene chromosomes (Satyaki et al. 2014) and pericentromeric heterochromatin of diploid nuclei (Blum et al. 2017), indicating that they may participate in chromocenter formation or its regulation. It would be of particular interest in the future to examine cell biological aspects of hybrid incompatibility to see whether they might present phenotypes that are consistent with these ideas (e.g., chromocenter disruption). It will also be of interest to examine the relationship between $\mathrm{Hmr}$ / Lhr and D1. 


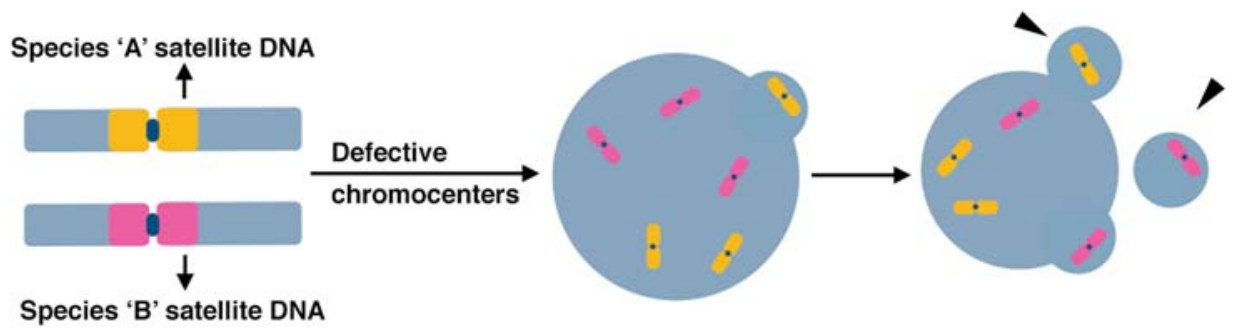

Figure 3. Hypothetical model of incompatibility between chromosomes from distinct species in forming chromocenter. The well-known fact that satellite DNA sequences are highly divergent between closely related species, combined with our finding that satellite DNA is critical for chromocenter formation and thus chromosome maintenance, leads to the question of whether chromosomes from different species can form chromocenters. We speculate that the incompatibility in chromocenter formation may underlie hybrid incompatibility.

\section{CONCLUSION}

As described above, here we present our hypothesis that chromocenter formation mediated by bundling of pericentromeric satellite DNA is a universal mechanism of eukaryotic cells to encapsulate the full complement of the genome into a single nucleus. Although satellite DNA function has remained enigmatic for a long time, our model offers explanations to many aspects of satellite DNA: lack of DNA sequence conservation, yet persistent presence in a broad range of eukaryotes, and cytological behavior of satellite DNA (chromocenter formation). Our model also provides several testable predictions, which need to be addressed in future studies. In summary, we propose that satellite DNA plays a fundamental role in the maintenance of the eukaryotic genome.

\section{ACKNOWLEDGMENTS}

The research in the Yamashita laboratory is supported by the Howard Hughes Medical Institute and the National Institute of General Medical Sciences (R01GM118308). M.J. is supported by a postdoctoral fellowship from the American Heart Association. We thank the Yamashita laboratory members for discussions.

\section{REFERENCES}

Allshire RC, Karpen GH. 2008. Epigenetic regulation of centromeric chromatin: Old dogs, new tricks? Nat Rev Genet 9: 923937.

Allshire RC, Madhani HD. 2017. Ten principles of heterochromatin formation and function. Nat Rev Mol Cell Biol doi: 10.1038/nrm.2017.119.

Aulner N, Monod C, Mandicourt G, Jullien D, Cuvier O, Sall A, Janssen S, Laemmli UK, Käs E. 2002. The AT-hook protein D1 is essential for Drosophila melanogaster development and is implicated in position-effect variegation. Mol Cell Biol 22: 1218-1232.

Baccarini P. 1908. Sulle cinesi vegetative del "Cynomorium coccineum L." N Giorn Bot Ital N Ser 15: 189-203.

Barbash DA, Siino DF, Tarone AM, Roote J. 2003. A rapidly evolving MYB-related protein causes species isolation in Drosophila. Proc Natl Acad Sci 100: 5302-5307.

Barry AE, Howman EV, Cancilla MR, Saffery R, Choo KH. 1999. Sequence analysis of an $80 \mathrm{~kb}$ human neocentromere. Hum Mol Genet 8: 217-227.

Bersani F, Lee E, Kharchenko PV, Xu AW, Liu M, Xega K, MacKenzie OC, Brannigan BW, Wittner BS, Jung H, et al. 2015. Pericentromeric satellite repeat expansions through
RNA-derived DNA intermediates in cancer. Proc Natl Acad Sci 112: 15148-15153.

Biamonti G, Vourc'h C. 2010. Nuclear stress bodies. Cold Spring Harb Perspect Biol 2: a000695.

Biscotti MA, Canapa A, Forconi M, Olmo E, Barucca M. 2015. Transcription of tandemly repetitive DNA: Functional roles. Chromosome Res 23: 463-477.

Blum JA, Bonaccorsi S, Marzullo M, Palumbo V, Yamashita YM, Barbash DA, Gatti M. 2017. The hybrid incompatibility genes $\mathrm{Lhr}$ and $\mathrm{Hmr}$ are required for sister chromatid detachment during anaphase but not for centromere function. Genetics 207: 1457-1472.

Bonaccorsi S, Pisano C, Puoti F, Gatti M. 1988. Y chromosome loops in Drosophila melanogaster. Genetics 120: 1015-1034.

Bonaccorsi S, Gatti M, Pisano C, Lohe A. 1990. Transcription of a satellite DNA on two Y chromosome loops of Drosophila melanogaster. Chromosoma 99: 260-266.

Bosco G, Campbell P, Leiva-Neto JT, Markow TA. 2007. Analysis of Drosophila species genome size and satellite DNA content reveals significant differences among strains as well as between species. Genetics 177: 1277-1290.

Bouzinba-Segard H, Guais A, Francastel C. 2006. Accumulation of small murine minor satellite transcripts leads to impaired centromeric architecture and function. Proc Natl Acad Sci 103: 8709-8714.

Brideau NJ, Flores HA, Wang J, Maheshwari S, Wang X, Barbash DA. 2006. Two Dobzhansky-Muller genes interact to cause hybrid lethality in Drosophila. Science 314: 1292-1295.

Brocher J, Vogel B, Hock R. 2010. HMGA1 down-regulation is crucial for chromatin composition and a gene expression profile permitting myogenic differentiation. BMC Cell Biol 11: 64.

Bühler M, Moazed D. 2007. Transcription and RNAi in heterochromatic gene silencing. Nat Struct Mol Biol 14: 1041-1048.

Burdick AB. 1976. Somatic cell chromosome interconnections in trypan preparations of Chinese hamster testicular cells. Exp Cell Res 99: 425-428.

Chang C-H, Larracuente AM. 2017. Genomic changes following the reversal of a Y chromosome to an autosome in Drosophila pseudoobscura. Evolution 71: 1285-1296.

Charlesworth B, Sniegowski P, Stephan W. 1994. The evolutionary dynamics of repetitive DNA in eukaryotes. Nature 371: 215-220.

Crasta K, Ganem NJ, Dagher R, Lantermann AB, Ivanova EV, Pan Y, Nezi L, Protopopov A, Chowdhury D, Pellman D. 2012. DNA breaks and chromosome pulverization from errors in mitosis. Nature 482: 53-58.

De Cecco M, Criscione S, Peterson A, Neretti N, Sedivy J, Kreiling J. 2013a. Transposable elements become active and mobile in the genomes of aging mammalian somatic tissues. Aging 5: 867-883.

De Cecco M, Criscione SW, Peckham EJ, Hillenmeyer S, Hamm EA, Manivannan J, Peterson AL, Kreiling JA, Neretti N, Sedivy JM. 2013b. Genomes of replicatively senescent cells undergo global epigenetic changes leading to gene silencing and activation of transposable elements. Aging Cell 12: 247-256. 
Dernburg AF, Sedat JW, Hawley RS. 1996. Direct evidence of a role for heterochromatin in meiotic chromosome segregation. Cell 86: 135-146.

du Sart D, Cancilla MR, Earle E, Mao JI, Saffery R, Tainton KM, Kalitsis P, Martyn J, Barry AE, Choo KH. 1997. A functional neo-centromere formed through activation of a latent human centromere and consisting of non- $\alpha$-satellite DNA. Nat Genet 16: 144-153.

Enukashvily NI, Donev R, Waisertreiger IS, Podgornaya OI. 2007. Human chromosome 1 satellite 3 DNA is decondensed, demethylated and transcribed in senescent cells and in A431 epithelial carcinoma cells. Cytogenet Genome Res 118: $42-54$.

Eymery A, Horard B, El Atifi-Borel M, Fourel G, Berger F, Vitte AL, Van den Broeck A, Brambilla E, Fournier A, Callanan M, et al. 2009. A transcriptomic analysis of human centromeric and pericentric sequences in normal and tumor cells. Nucleic Acids Res 37: 6340-6354.

Fry K, Salser W. 1977. Nucleotide sequences of HS- $\alpha$ satellite DNA from kangaroo rat Dipodomys ordii and characterization of similar sequences in other rodents. Cell 12: 1069-1084.

Fukagawa T, Earnshaw WC. 2014. The centromere: Chromatin foundation for the kinetochore machinery. Dev Cell 30: 496508.

Garrido-Ramos MA. 2017. Satellite DNA: An evolving topic. Genes (Basel) 8: E230 doi: 10.3390/genes8090230.

Gaubatz JW, Cutler RG. 1990. Mouse satellite DNA is transcribed in senescent cardiac muscle. $J$ Biol Chem 265: 17753-17758.

Goodwin GH, Sanders C, Johns EW. 1973. A new group of chromatin-associated proteins with a high content of acidic and basic amino acids. Eur J Biochem 38: 14-19.

Guelen L, Pagie L, Brasset E, Meuleman W, Faza MB, Talhout W, Eussen BH, de Klein A, Wessels L, de Laat W, et al. 2008. Domain organization of human chromosomes revealed by mapping of nuclear lamina interactions. Nature 453: 948-951.

Guenatri M, Bailly D, Maison C, Almouzni G. 2004. Mouse centric and pericentric satellite repeats form distinct functional heterochromatin. J Cell Biol 166: 493-505.

Hahn M, Dambacher S, Dulev S, Kuznetsova AY, Eck S, Wörz S, Sadic D, Schulte M, Mallm JP, Maiser A, et al. 2013. Suv4-20h2 mediates chromatin compaction and is important for cohesin recruitment to heterochromatin. Genes Dev 27: 859-872.

Haider S, Cordeddu L, Robinson E, Movassagh M, Siggens L, Vujic A, Choy M-K, Goddard M, Lio P, Foo R. 2012. The landscape of DNA repeat elements in human heart failure. Genome Biol 13: R90.

Hall LE, Mitchell SE, O’Neill RJ. 2012. Pericentric and centromeric transcription: A perfect balance required. Chromosome Res 20: 535-546.

Hall LL, Byron M, Carone DM, Whitfield TW, Pouliot GP, Fischer A, Jones P, Lawrence JB. 2017. Demethylated HSATII DNA and HSATII RNA foci sequester PRC1 and MeCP2 into cancer-specific nuclear bodies. Cell Rep 18: 2943-2956.

Hatch EM, Hetzer MW. 2015. Chromothripsis. Curr Biol 25: R397-R399.

Hatch EM, Fischer AH, Deerinck TJ, Hetzer MW. 2013. Catastrophic nuclear envelope collapse in cancer cell micronuclei. Cell 154: 47-60.

Hawley RS, Irick H, Zitron AE, Haddox DA, Lohe A, New C, Whitley MD, Arbel T, Jang J, McKim K, Childs G. 1992. There are two mechanisms of achiasmate segregation in Drosophila females, one of which requires heterochromatic homology. Dev Genet 13: 440-467.

Heikkinen E, Launonen V, Müller E, Bachmann L. 1995. The pvB370 BamHI satellite DNA family of the Drosophila virilis group and its evolutionary relation to mobile dispersed genetic pDv elements. J Mol Evol 41: 604-614.

Heitz E. 1928. Das Heterochromatin der Moose.I. Jahrb Wiss Bot 69: $762-818$.

Henikoff S, Ahmad K, Malik H. 2001. The centromere paradox: Stable inheritance with rapidly evolving DNA. Science 293: 1098-1102.
Huth JR, Bewley CA, Nissen MS, Evans JN, Reeves R, Gronenborn AM, Clore GM. 1997. The solution structure of an HMGI(Y)-DNA complex defines a new architectural minor groove binding motif. Nat Struct Biol 4: 657-665.

Hutter P, Ashburner M. 1987. Genetic rescue of inviable hybrids between Drosophila melanogaster and its sibling species. $\mathrm{Na}$ ture 327: 331-333.

John B, Miklos GL. 1979. Functional aspects of satellite DNA and heterochromatin. Int Rev Cytol 58: 1-114.

Johnson WL, Yewdell WT, Bell JC, McNulty SM, Duda Z, O'Neill RJ, Sullivan BA, Straight AF. 2017. RNA-dependent stabilization of SUV39H1 at constitutive heterochromatin. Elife 6: e25299.

Jolly C, Metz A, Govin J, Vigneron M, Turner BM, Khochbin S, Vourc'h C. 2004. Stress-induced transcription of satellite III repeats. J Cell Biol 164: 25-33.

Jones KW. 1970. Chromosomal and nuclear location of mouse satellite DNA in individual cells. Nature 225: 912-915.

Joseph A, Mitchell AR, Miller OJ. 1989. The organization of the mouse satellite DNA at centromeres. Exp Cell Res 183: 494 500 .

Joshi SS, Meller VH. 2017. Satellite repeats identify X chromatin for dosage compensation in Drosophila melanogaster males. Curr Biol 27: 1393-1402.e2.

Kapitonov VV, Holmquist GP, Jurka J. 1998. L1 repeat is a basic unit of heterochromatin satellites in cetaceans. Mol Biol Evol 15: 611-612.

Karpen GH, Allshire RC. 1997. The case for epigenetic effects on centromere identity and function. Trends Genet 13: 489496.

Kidwell MG. 2002. Transposable elements and the evolution of genome size in eukaryotes. Genetica 115: 49-63.

Kit S. 1961. Equilibrium sedimentation in density gradients of DNA preparations from animal tissues. J Mol Biol 3: 711-716.

Kuhn G, Küttler H, Moreira-Filho O. 2011. The 1.688 repetitive DNA of Drosophila: Concerted evolution at different genomic scales and association with genes. Mol Biol Evol 29: 7-11.

Kuznetsova IS, Enukashvily NI, Noniashvili EM, Shatrova AN, Aksenov ND, Zenin VV, Dyban AP, Podgornaya OI. 2007. Evidence for the existence of satellite DNA-containing connection between metaphase chromosomes. $J$ Cell Biochem 101: 1046-1061.

Kuznetsova IS, Ostromyshenskii DI, Komissarov AS, Prusov AN, Waisertreiger IS, Gorbunova AV, Trifonov VA, Ferguson-Smith MA, Podgornaya OI. 2016. LINE-related component of mouse heterochromatin and complex chromocenters' composition. Chromosome Res 24: 309-323.

Levinger L, Varshavsky A. 1982a. Protein D1 preferentially binds A + T-rich DNA in vitro and is a component of Drosophila melanogaster nucleosomes containing A + T-rich satellite DNA. Proc Natl Acad Sci 79: 7152-7156.

Levinger L, Varshavsky A. 1982b. Selective arrangement of ubiquitinated and D1 protein-containing nucleosomes within the Drosophila genome. Cell 28: 375-385.

Locke DP, Hillier LW, Warren WC, Worley KC, Nazareth LV, Muzny DM, Yang S-P, Wang Z, Chinwalla AT, Minx P, et al. 2011. Comparative and demographic analysis of orangutan genomes. Nature 469: 529-533.

Lohe AR, Hilliker AJ, Roberts PA. 1993. Mapping simple repeated DNA sequences in heterochromatin of Drosophila melanogaster. Genetics 134: 1149-1174.

Lund T, Holtlund J, Fredriksen M, Laland SG. 1983. On the presence of two new high mobility group-like proteins in HeLa S3 cells. FEBS Lett 152: 163-167.

Lyon MF, Searle AG. 1989. Genetic variants and strains of the laboratory mouse. Oxford University Press, Oxford.

Malik HS. 2009. The centromere-drive hypothesis: A simple basis for centromere complexity. Prog Mol Subcell Biol 48: $33-52$.

Mayer R, Brero A, von Hase J, Schroeder T, Cremer T, Dietzel S. 2005. Common themes and cell type specific variations of higher order chromatin arrangements in the mouse. $B M C$ Cell Biol 6: 44 
Menon DU, Coarfa C, Xiao W, Gunaratne PH, Meller VH. 2014. siRNAs from an X-linked satellite repeat promote X-chromosome recognition in Drosophila melanogaster. Proc Natl Acad Sci 111: 16460-16465.

Meuleman W, Peric-Hupkes D, Kind J, Beaudry JBB, Pagie L, Kellis M, Reinders M, Wessels L, van Steensel B. 2013. Constitutive nuclear lamina-genome interactions are highly conserved and associated with A/T-rich sequence. Genome Res 23: 270-280.

Miklos GL, John B. 1979. Heterochromatin and satellite DNA in man: Properties and prospects. Am J Hum Genet 31: 264280.

Moazed D. 2011. Mechanisms for the inheritance of chromatin states. Cell 146: 510-518.

Nishibuchi G, Déjardin J. 2017. The molecular basis of the organization of repetitive DNA-containing constitutive heterochromatin in mammals. Chromosome Res 25: 77-87.

Ohno S. 1972. So much "junk" DNA in our genome. Brookhaven Symp Biol 23: 366-370.

Orgel LE, Crick FHC. 1980. Selfish DNA: The ultimate parasite. Nature 284: 604-607.

Pardue ML, Gall JG. 1970. Chromosomal localization of mouse satellite DNA. Science 168: 1356-1358.

Peters AH, O'Carroll D, Scherthan H, Mechtler K, Sauer S, Schöfer C, Weipoltshammer K, Pagani M, Lachner M, Kohlmaier A, et al. 2001. Loss of the Suv39h histone methyltransferases impairs mammalian heterochromatin and genome stability. Cell 107: 323-337.

Pezer Z, Ugarkovic D. 2012. Satellite DNA-associated siRNAs as mediators of heat shock response in insects. RNA Biol 9: 587-595.

Pinheiro I, Margueron R, Shukeir N, Eisold M, Fritzsch C, Richter FM, Mittler G, Genoud C, Goyama S, Kurokawa M, et al. 2012. Prdm3 and Prdm16 are H3K9me1 methyltransferases required for mammalian heterochromatin integrity. Cell 150: 948-960.

Piras FM, Nergadze SG, Magnani E, Bertoni L, Attolini C, Khoriauli L, Raimondi E, Giulotto E. 2010. Uncoupling of satellite DNA and centromeric function in the genus Equus. PLoS Genet 6: e1000845.

Pisano C, Bonaccorsi S, Gatti M. 1993. The kl-3 loop of the Y chromosome of Drosophila melanogaster binds a tektin-like protein. Genetics 133: 569-579.

Probst AV, Okamoto I, Casanova M, El Marjou F, Le Baccon P, Almouzni G. 2010. A strand-specific burst in transcription of pericentric satellites is required for chromocenter formation and early mouse development. Dev Cell 19: 625-638.

Radic MZ, Saghbini M, Elton TS, Reeves R, Hamkalo BA. 1992. Hoechst 33258, distamycin A, and high mobility group protein I (HMG-I) compete for binding to mouse satellite DNA. Chromosoma 101: 602-608.

Rae MM, Franke WW. 1972. The interphase distribution of satellite DNA-containing heterochromatin in mouse nuclei. Chromosoma 39: 443-456.

Reeves R, Nissen MS. 1990. The A.T-DNA-binding domain of mammalian high mobility group I chromosomal proteins. A novel peptide motif for recognizing DNA structure. $J$ Biol Chem 265: 8573-8582.

Rizzi N, Denegri M, Chiodi I, Corioni M, Valgardsdottir R, Cobianchi F, Riva S, Biamonti G. 2004. Transcriptional activation of a constitutive heterochromatic domain of the human genome in response to heat shock. Mol Biol Cell 15: 543551.

Rodriguez Alfageme C, Rudkin GT, Cohen LH. 1980. Isolation, properties and cellular distribution of $\mathrm{D} 1$, a chromosomal protein of Drosophila. Chromosoma 78: 1-31.

Rosin LF, Mellone BG. 2017. Centromeres drive a hard bargain. Trends Genet 33: 101-117.

Saksouk N, Simboeck E, Déjardin J. 2015. Constitutive heterochromatin formation and transcription in mammals. Epigenetics Chromatin 8: 3 .

Salser W, Bowen S, Browne D, el-Adli F, Fedoroff N, Fry K, Heindell H, Paddock G, Poon R, Wallace B, et al. 1976. In- vestigation of the organization of mammalian chromosomes at the DNA sequence level. Fed Proc 35: 23-35.

Satyaki PR, Cuykendall TN, Wei KH, Brideau NJ, Kwak H, Aruna S, Ferree PM, Ji S, Barbash DA. 2014. The Hmr and $L h r$ hybrid incompatibility genes suppress a broad range of heterochromatic repeats. PLoS Genet 10: e1004240.

Sawamura K. 2012. Chromatin evolution and molecular drive in speciation. Int J Evol Biol 2012: 301894.

Schueler MG, Higgins AW, Rudd MK, Gustashaw K, Willard HF. 2001. Genomic and genetic definition of a functional human centromere. Science 294: 109-115.

Shirai A, Kawaguchi T, Shimojo H, Muramatsu D, Ishida-Yonetani M, Nishimura Y, Kimura H, Nakayama JI, Shinkai Y. 2017. Impact of nucleic acid and methylated H3K9 binding activities of Suv39h1 on its heterochromatin assembly. Elife 6: e25317.

Shumaker DK, Dechat T, Kohlmaier A, Adam SA, Bozovsky MR, Erdos MR, Eriksson M, Goldman AE, Khuon S, Collins FS, et al. 2006. Mutant nuclear lamin A leads to progressive alterations of epigenetic control in premature aging. Proc Natl Acad Sci 103: 8703-8708.

Smith MB, Weiler KS. 2010. Drosophila D1 overexpression induces ectopic pairing of polytene chromosomes and is deleterious to development. Chromosoma 119: 287-309.

Stephan W, Cho S. 1994. Possible role of natural selection in the formation of tandem-repetitive noncoding DNA. Genetics 136: 333-341.

Stephens AD, Liu PZ, Banigan EJ, Almassalha LM, Backman V, Adam SA, Goldman RD, Marko JF. 2018. Chromatin histone modifications and rigidity affect nuclear morphology independent of lamins. Mol Biol Cell. 29: 220-233.

Strauss F, Varshavsky A. 1984. A protein binds to a satellite DNA repeat at three specific sites that would be brought into mutual proximity by DNA folding in the nucleosome. Cell 37: 889901.

Sueoka N. 1961. Variation and heterogeneity of base composition of deoxyribonucleic acids: A compilation of old and new data. J Mol Biol 3: 31-40.

Sun X, Wahlstrom J, Karpen G. 1997. Molecular structure of a functional Drosophila centromere. Cell 91: 1007-1019.

Sun X, Le HD, Wahlstrom JM, Karpen GH. 2003. Sequence analysis of a functional Drosophila centromere. Genome Res 13: $182-194$.

Sybalski W. 1968. Use of cesium sulfate for equilibrium density gradient centrifugation. Methods Enzymol 12(Pt B): 330-360.

Takayama S. 1975. Interchromosomal connectives in squash preparations of L cells. Exp Cell Res 91: 408-412.

Tasselli L, Xi Y, Zheng W, Tennen RI, Odrowaz Z, Simeoni F, Li W, Chua KF. 2016. SIRT6 deacetylates H3K18ac at pericentric chromatin to prevent mitotic errors and cellular senescence. Nat Struct Mol Biol 23: 434-440.

Ting DT, Lipson D, Paul S, Brannigan BW, Akhavanfard S, Coffman EJ, Contino G, Deshpande V, Iafrate AJ, Letovsky $\mathrm{S}$, et al. 2011. Aberrant overexpression of satellite repeats in pancreatic and other epithelial cancers. Science 331: 593596.

Ugarković D, Plohl M. 2002. Variation in satellite DNA profiles - Causes and effects. EMBO J 21: 5955-5959.

Valgardsdottir R, Chiodi I, Giordano M, Rossi A, Bazzini S, Ghigna C, Riva S, Biamonti G. 2008. Transcription of satellite III non-coding RNAs is a general stress response in human cells. Nucleic Acids Res 36: 423-434.

Velazquez Camacho O, Galan C, Swist-Rosowska K, Ching R, Gamalinda M, Karabiber F, De La Rosa-Velazquez I, Engist B, Koschorz B, Shukeir N, et al. 2017. Major satellite repeat RNA stabilize heterochromatin retention of Suv39h enzymes by RNA-nucleosome association and RNA:DNA hybrid formation. Elife 6: e25293.

Vissel B, Choo KH. 1989. Mouse major $(\gamma)$ satellite DNA is highly conserved and organized into extremely long tandem arrays: Implications for recombination between nonhomologous chromosomes. Genomics 5: 407-414. 
Vogel B, Löschberger A, Sauer M, Hock R. 2011. Cross-linking of DNA through HMGA1 suggests a DNA scaffold. Nucleic Acids Res 39: 7124-7133.

Voullaire LE, Slater HR, Petrovic V, Choo KH. 1993. A functional marker centromere with no detectable $\alpha$-satellite, satellite III, or CENP-B protein: Activation of a latent centromere? Am J Hum Genet 52: 1153-1163.

Wade CM, Giulotto E, Sigurdsson S, Zoli M, Gnerre S, Imsland F, Lear TL, Adelson DL, Bailey E, Bellone RR, et al. 2009. Genome sequence, comparative analysis, and population genetics of the domestic horse. Science 326: 865-867.

Walker PM. 1971. Origin of satellite DNA. Nature 229: 306308.

Watanabe TK. 1979. A gene that rescues the lethal hybrids between Drosophila melanogaster and Drosophila simulans. Jpn $J$ Genet 54: 325-331.

Willard HF. 1990. Centromeres of mammalian chromosomes. Trends Genet 6: 410-416.
Wong A, Rattner J. 1988. Sequence organization and cytological localization of the minor satellite of mouse. Nucleic Acids Res 16: 11645-11661.

Yunis JJ, Yasmineh WG. 1971. Heterochromatin, satellite DNA, and cell function. Structural DNA of eucaryotes may support and protect genes and aid in speciation. Science 174: 1200-1209.

Zeller P, Padeken J, van Schendel R, Kalck V, Tijsterman M, Gasser SM. 2016. Histone H3K9 methylation is dispensable for Caenorhabditis elegans development but suppresses RNA: DNA hybrid-associated repeat instability. Nat Genet 48: 1385 1395.

Zhang C-Z, Spektor A, Cornils H, Francis JM, Jackson EK, Liu S, Meyerson M, Pellman D. 2015. Chromothripsis from DNA damage in micronuclei. Nature 522: 179-184.

Zhu Q, Pao GM, Huynh AM, Suh H, Tonnu N, Nederlof PM, Gage FH, Verma IM. 2011. BRCA1 tumour suppression occurs via heterochromatin-mediated silencing. Nature 477: 179-184. 


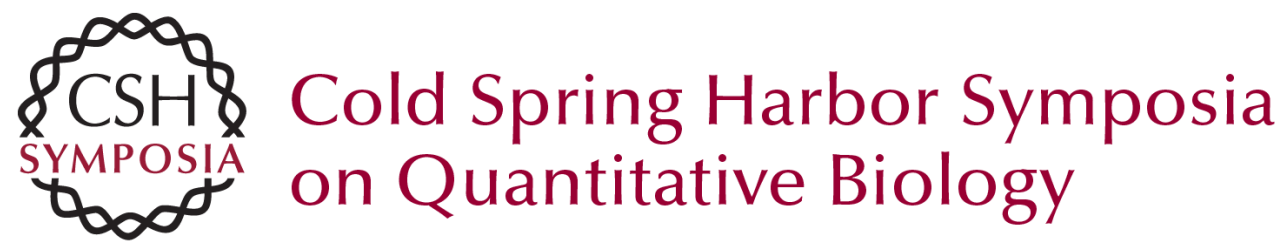

\section{Function of Junk: Pericentromeric Satellite DNA in Chromosome Maintenance}

Madhav Jagannathan and Yukiko M. Yamashita

Cold Spring Harb Symp Quant Biol 2017 82: 319-327 originally published online April 2, 2018 Access the most recent version at doi:10.1101/sqb.2017.82.034504

References This article cites 119 articles, 31 of which can be accessed free at: http://symposium.cshlp.org/content/82/319.full.html\#ref-list-1

Creative This article is distributed under the terms of the

Commons http://creativecommons.org/licenses/by-nc/4.0/, which permits reuse and License redistribution, except for commercial purposes, provided that the original author and source are credited.

Email Alerting Receive free email alerts when new articles cite this article - sign up in Service the box at the top right corner of the article or click here. 